\title{
Tangible or Intangible Ways to Happiness? Consumption Related Values Among
} Adolescents

\author{
János Debreceni \\ Budapesti Gazdasági Egyetem,Budapest
}

\begin{abstract}
In recent years a large number of consumer studies focused on happiness, subjective well-being and satisfaction with life in relationship with material or experimental consumption. Most of the studies applied statistically reliable validated scales and measurements involving large numbers of respondents. There are only a few study that aimed to answer the meaning of happiness or satisfaction and their reflections in adolescents' consumer behaviour at the present time. Due to the less represented academic literature in that area and the controversial results of our previous quantitative research on materialism we decided to conduct a qualitative research to investigate the meaning of happiness among adolescents in Hungary. Our non-representative sample consisted of students from 5 different high schools in 3 cities including Budapest. Respondents took part in in-depth interviews, peer interviews and worked in groups in associative experiments. According to our findings physical goods and material consumption contribute less to the individuals' sense of happiness and interpersonal relationships are more appreciated. The teenagers of our sample showed signs of material emptiness, since possessing things were unimportant for them Family, stable personal relationships and safety were very significant among their values. Their consumer behaviour was influenced mostly by the need for gaining experiences rather than need for acquisition and possession of tangible goods.
\end{abstract}

Keywords: tangible or intangible ways to happiness, consumption related values among adolescents

\section{Introduction}

In consumer society human needs are satisfied through the acquisition, possession and the use of goods or the consumption of services. In recent postmodern age the consumption is not solely about need satisfactions but the expression of individuals' social and economic state. The ways and costs of the act of consuming are the reflections of the consumers' income and position in social order. Their consumption related desires or dreams predict future lifestyles and life trajectories. Naturally the consuming power and potential gain individuals' satisfaction with life and sense of wealth. The consumers' perceived economic state - that can be described by their consuming potential - may increase their satisfaction with life. This is a relatively constant state of existence owing to pervious achievements, successes and goals realized. In opposite of satisfaction happiness is rather a joyful emotion-driven moment, a temporary feeling of endless pleasure. The length of this moment is variable and it is very fragile. Happiness functions as flows in someone's life (Csíkszentmihályi, 2002). Undoubtedly happy moments and flows contribute to the satisfaction with life. Today's culture of consumption is ruled by the desire for acquisiting newer and more goods. Possessing the latest versions are often considered as one of the source of happiness and through the mass media, social media and advertisments it is strongly connected with satisfaction with life. Whether what is the role of material goods in consumers' feeling of happiness and satisfaction with their life? This was one of research perspectives in recent study. On the other hand the role of values in consumer behaviour was another perspective. In several value concepts happiness is a terminal value or preferred state of existence. Instrumental values are helping individuals to achieve terminal states. Materialism is the individuals' attachment of worldy possessions described and investigated through personal traits like possessiveness, non-generosity and envy (Belk, 1983) or acquisition centrality, success and happiness (Richins-Dawson, 1992). Due to its organizing function and power on everyday activities, decisions or lifestyle, materialism can be considered as an instrumental value. Whether materialism, possessiveness and acquisitiveness are gaining happiness? The relationship between values, materialism and happiness was investigated among teenagers. Adolescence as a crucial liminal transition in individuals' life is a proper age for 
observing the influence of material possessions and consumerism. Earlier a large number of consumer studies focused on happiness, subjective well-being and satisfaction with life in relationship with material or experimental consumption. Most of the studies applied statistically reliable validated scales and measurements involving large numbers of respondents. There are only a few studies aiming to answer the meaning of happiness or satisfaction and their reflections in adolescents' consumer behaviour at the present time. Due to the less represented academic literature in that area and the controversal results of our previous quantitative research on materialism was decided to conduct a qualitative research to investigate the meaning of happiness among adolescents in Hungary.

\section{The role of values in consumer behaviour}

Human values are the drivers of behaviour and determine personal goals, aims and perspectives. According to Schwartz values play a significant role in people's life influencing their lifestyles and emotions (Schwartz, 2006). In Rokeach's definition value is an enduring belief, a specific mode of conduct or end state of existence (Rokeach, 1973). Attitudes are similar like values but less strong predictors of human behaviour moreover values are more stable concepts over time (Varga, 2003). Morris distinguished three varieties of values based on their capability to influence human behaviour and defined inherent, conceived and operative values. The inherent values drive individual behaviour, while conceived mean the preferred state of existence. The conceived values often represent contradictions, people know and understand the ways to be more satisfied, happy or healthy but they do only a few or no efforts to realize a better state of existence. The objective values are related to the objects, materials and physical assets those are necessary to survive or be well (Varga, 2003). Rokeach involved a bilateral set of values and created the concept of terminal and instrumental values. Terminals cover the preferred states of existence such as happiness, freedom or wisdom. Instrumentals are the ways to reach the preferred states like brave, intelligent or reliable (Hofmeister, 2014). The Rokeach Value Survey (RVS) consists of 18 terminal and 18 instrumental values to rank by respondents. Although RVS was the first instrument to measure the importance of individuals' value system, it was criticized due to the multiple meanings of values (GibbinsWalker, 1993). Among others Kahle and her co-authors also developed the List of Value (LOV) set from the theoretical base of Feather (degree of motivation), Maslow (hierarchy of needs) and Rokeach Value Survey (Kahle et al. 1984). LOV consists of 9 values: being well respected, excitement, fun and enjoyment, security, self-fulfilment, self-respect, sense of accomplishment, sense of belonging, warm relationships with others. LOV items can be distinguished on the internal and external nature of control. Externals are the security, sense of belonging and being well-respected, the rests are internal values. According to the role of personality in fulfilment, LOV items can be interpersonal (e.g. warm relationships with others) or personal values (e.g. self-respect). Among value researchers Hofstede was the first who found quantitative evidences on the differences of values between cultures. He characterized 6 dimensions: power distance, individualism or collectivism, masculinity or femininity, uncertainty avoidance, long or short term orientation, restraint. (Hofstede Hofstede, 2010) These 6 dimensions are appropriate to characterize a national culture and distinguish it from others. Hofstede's concept was successfully applied both in business practices and academic researches. Hofstede has also drawn up an onion shaped model that represents how a value functions in everyday livings, practices, decision-makings or preferences. Values are the core, the first layer consists of rituals (mode of living, routines) heroes (people admired performing rituals excellent) and symbols (objects manifesting the meaning of inner layers). Inglehart is credited with his foundational work on the theory of value change linked to assessing materialism (Hofmeister-TóthEibel-Spányi, 2013). In his book The silent revolution (Inglehart, 1977) characterizes the nature of consumer society development. He argues the values in society are changing towards an emancipatory way instead of the direction of conventions or traditions. Owing to consumerism the self was placed into a centred position and the former value order that directed the individuals' decision and behaviour became powerless. On one hand this phenomena can be explained by the consumer hedonism (Campell, 2005) that means the lasting satisfaction of needs is impossible due to the consumer's weakness against market impressions, he wants more and more and desires the latest goods or services. On the other hand the sellers on the market are interested in launching newer lines in order to force their consumers to buy again their products. In postmodern societies the self is described as a consumer with his potential. Individuals create their future ideal selves as consumers then they find ways to realize it, instead of modernity's profession or calling driven life trajectories (Bauman, 1991). Instead of ensuring tomorrow the "here and now" catchword determines consumer decision-making. The clear sign of success is the potential and readiness for immediate consumption. Thus consumerism and its parallel developing with post-modern culture gained the importance of material goods in consumers' sense of satisfaction with life, well-being and happiness. 
Materialism as a value

Beside other disciplines marketing also considers values as strong predictors of human behaviour. Consumption studies confirmed the reflections of values in consumer behaviours: pre-decision, decision and post-decision stages as well. In consumer society human needs are satisfied mainly through buying goods or services. The formation of consumer society had been accelerated during the industrial revolution in the $19^{\text {th }}$ century. The market and social development fundamentally changed the relationship between human subject and material object. The first impacts were the changes in the value inuse and in-exchange of material goods; the anthropomorphisation of commodities (Marx) and the diversity in consumer habits at different social layers (Veblen). From the early 1900's until the '60s consumerism related theories had been divergent. The consumption as the object of investigation was placed into the context of psychological processes (Freud and his followers), religion (Weber), philosophy (Hobhouse, McDonald), social order (Tawney) modern life (Benjamin) gift theory (Mauss) and mass culture (Adorno, Horkheimer). Between 60s and 80s consumers as individuals had been highlighted and examined according to their daily routines and latencies behind (Fromm, Riesman, Lefebvre). The 1980s predetermined the rest of 20th century consumption studies. Pierre Bourdieu's work Distinction (1987) has become a basic literature for researchers but McKendrick's The Birth of Consumer Society (1982) and Collin Campbell's The Romantic Ethic and the Spirit of Modern Consumerism (1987) also achieved success and popularity among academics. In the 80s a new paradigm was formed materialism.

Earlier it was defined as a mind-set, an interest in getting and spending (RassuliHollander, 1968) or a cultural system in which material interests are not made subservient to other social goals (Mukerji, 1983). Csíkszentmihályi distinguished two types of materialism: instrumental if the material objects are essential for discovering and furthering personal goals and values. Terminal if consumption furthers no goal beyond possession itself (CsíkszentmihályiRochberg-Halton, 1978). Based on a remarkable review on different literature in the context of material goods, Russel W. Belk emerged three questions (Belk, 1983): Is acquisitiveness unavoidable? Is possessiveness unavoidable? Does altruism exist? Belk selected personal traits as possessiveness, non-generosity and envy to develop his instrument to measure the level of materialism. In his interpretation materialism is the importance a consumer attaches to worldly possessions (Belk, 1984). Belk's materialism scale became successful among academics and marketing specialists. Later Richins and Dawson retested previously published materialism scales and found them unreliable except of Belk's scale. During the development of their own scale they placed emphasis on the psychometric properties of the scale. Previously Fournier and Richins argued materialism is inseparable from people's mind-set and acquisitiveness and possessiveness are primary important in the determination of people's lifestyle or the relationship with others. (FournierRichins, 1991). According to them materialism is a value that guides people's choices and conducting in different situations but not only in the context of consumption. Due to the organizing function of acquisition and the prioritizing material possessions in life, materialism is definitely a value (RichinsDawson, 1992). With respect to general preferences materialists may work longer time instead of leisure, or tend to earn more money in order to realize their material desires. (RichinsDawson, 1992). Based on several previous findings they denoted four special characteristics of materialist people: for materialist the acquisition and possession of things is more important, they are self-centred, less satisfied with their life and aim material complexity rather than simplicity (RichinsDawson, 1992). According to their propositions and as the results of scale development and item refinement Richins and Dawson proposed to measure materialism through three dimensions: success, centrality of material possessions and happiness. Ten years later Tim Kasser published his book The High Price of Materialism (2002) reaching popularity among academic and non-academic readers too. Based on his experiences as a psychologist, Kasser highlighted materialism as the antecedent of subjective well-being, psychological needs, happiness, uncertainty or selfesteem. His work was a reflection on the dilemmas, problems and constraints in North American lifestyles. Kasser criticized post-modern capitalist culture, the misleading marketing and advertising campaigns, and the superficial and material life goals leading individuals to personal crisis and disorders. In their previous scientific works with Richard Ryan they developed Aspiration Index by which they found evidences on the importance of materialism among values. According to them materialism is a value based on the desire of wealth, possessions, image and social state. Kasser derived general conclusions about the negative impact of materialism on physical and mental well-being, vitality and self-fulfillment, susceptibility to depression, anxiety and the sense of happiness. Most of these variables and their relationship with materialism are examined in latest interdisciplinary scientific studies. 
Tendencies in researching materialism

In the last 8 years published studies in materialism related topics are based on the conceptions of Belk, Richins-Dawson or Kasser. Between 2010 and 2017 there were more than 120 reviewed articles in this field. These papers can be classified into 3 groups namely consumer habits, subjective well-being and satisfaction with life (Debreceni, 2018). Studies on consumer habits are about compulsive buying, luxury-, experimental and status consumption. Compulsive buying is a response to an uncontrollable drive or desire that leads an individual to repetitively engage in a behaviour (such as buying) that will ultimately cause harm to the individual (Weaver et al. 2011). Its relationship with materialism is proved (Moschis et al. 2013; Gardasdóttir Dittmar, 2012; Weaver et al. 2011) and it can be intensified by personal traits such as narcissism (Harnish Bridges, 2014). Luxury consumption means the preferences towards luxury brands, products. Luxury consumers are usually more materialist and in a short term they are more vital and satisfied with their life (Hudders Pandelaere, 2011) but luxury can influence other choices and preferences too (Audrin et al. 2017). Experimental consumption is the opposite of material consumption aiming to gain experiences, insights, personal involvement. Experimental consumption fosters positive self-perceptions, gains subjective well-being (CarterGilovich, 2012) and contributes more to the sense of happiness than material consumption (Zhang et al. 2014). Status consumption is the driven by the desire to possess and use status symbols. Status consumption has a mediatory role between status consumer and its environment (Goldsmith Clark, 2012). Rather materialist people are prone to consume status symbols, are more innovative and have strong brand identity (Flynn et al. 2016).

Variables in connection with materialism detailed above are decisions or subordinated to consumer decisions. In contrast subjective well-being is temporary state of someone which includes satisfaction with life, past decisions and personal development. Based on Kasser's concept scientific studies found more materialist people are less satisfied with their life (Jiang et al. 2016), in other words not-superficial but higher-order values and life goals contributes more to the well-being (MartosKopp, 2012). Material orientation can lead to constant dissatisfaction (Deckop et al. 2010). for instance compulsive buyers are not satisfied in the least with their life (Villadefrancos Otero-Lopez, 2016).

Resarches involving Hungarian samples found materialism negatively associated with satisfaction, subjective well-being or happiness. According to Szondy (2007) material possessions contributes less to the sense of happiness over a basic level of need satisfaction. Pikó (2006) applied Richins-Dawson materialism scale and found satisfaction with life positively associated with material success and negatively with happiness. Based on a representative sample, Hofmeister and Neulinger proved generational defferences (HofmeisterNeulinger, 2013). Respondents born in the era of socialist regime were characterized with a higher level of possessiveness but generous in opposite of less materialist respondents born after the change of regime. In this context the level of materialism can be influenced by the social-political environment. In that study Hofmeister and Neulinger compared responses settled in two time period with 7 years difference. They found evidences on the development of consumerism for instance renting and leasing became known and more accepted constructs.

An exploratory study design

In consideration of the latest materialism conclusions, the characteristics of Hungarian people, the impact of values as predictors and the importance of liminal transitions in changes in values (Weber, 1915) an exploratory research was designed proposing the following two research questions:

$R Q 1:$ What do materialism related constructs mean to teenagers: money, success, happiness, status symbol, experience, satisfaction and materialism?

\section{$R Q 2:$ What other interrelationships can exist?}

In recent research adolescents were chosen as target group because adolescence - as a liminal transition - is a very important life period regarding the consumer socialization (John, 1999). Instead of a static rigourus method a dynamic interactive based method was conducted. It may worsen reliability, repeatability and generalizability features of the study but provides more insights into the phenomena which is examined usually in a quantitative way. Recent study consisted of three different but interrelated stages. The first stage was a set of semi-structured in-depth interviews in one-to-one and in peer group formations. The structure was based on life goals, satisfaction with life, values, happiness, importance of money, materialism. Interviewees could explain their views and perspectives in a narrative way. The second stage was a peer work exercise taken by a high school class. Participants were sorted into 3-4 person group and their task was to find as many 
associations as they could in connection with the items of List of Values Kahlet et al. 1984) and materialism. Then they had to cut off the half of their findings and retain the most relevant ones. As a last step they had to sort the retained association according to their relevance. Each group had to characterize 2 different and 3 common items. These 3 were the security, sense of accomplishment and the materialism. The last is given by the research aim but the 2 values are common because in our previous quantitative study security was found the most while sense of accomplishment the least important value among teenagers (DebreceniHofmeister, 2018). The third stage consisted of a similar associative task but instead of values it included materialism related definitions, namely money, success, status symbol, experience, happiness and materialism. There was an additional exercise done during in-depth interviews in one-to-one and peer group formations, it was a photo collage. From a set of images (people, material possessions, achievement, sport and leisure categories) the respondents had to select those photos those contribute the most to their sense of happiness (ChaplinJohn, 2010) Due to the age of respondents luxury consumption and compulsive buying could not be examined. These two constructs are belonging to those people who earn their own money and have a remarkable spending power. Students in Hungary are depending on their parents' income and their spendings can be characterized well (Pál, 2013) nevertheless regarding the Hungarian society only a less than $1 \%$ can afford luxury consumption (Tóth, 2016). Beside luxury consumption compulsive buying was excluded because it is related to the field of psychology.

\section{Sample characteristics}

\begin{tabular}{|c|c|c|c|c|c|c|c|}
\hline \multirow{2}{*}{ Stage } & \multirow{2}{*}{ City } & \multirow{2}{*}{ Type } & \multirow{2}{*}{ Method } & \multirow{2}{*}{ Instrument } & \multicolumn{2}{|c|}{ Respondents } & \multirow{2}{*}{ Date } \\
\hline & & & & & Female & Male & \\
\hline \multirow{4}{*}{ I. } & \multirow{2}{*}{ Budapest } & \multirow{2}{*}{$\begin{array}{l}\text { Vocational } \\
\text { school }\end{array}$} & $\begin{array}{l}\text { In-depth interview } \\
\text { One-to-one }\end{array}$ & \multirow{4}{*}{$\begin{array}{l}\text { Terminal and } \\
\text { instrumental } \\
\text { values } \\
\text { Happiness } \\
\text { Materialism } \\
\text { Satisfaction with } \\
\text { life }\end{array}$} & 1 & 2 & 29.01 .18 \\
\hline & & & $\begin{array}{l}\text { Interview } \\
\text { Peer group }\end{array}$ & & 2 & 1 & 29.01 .18 \\
\hline & \multirow{2}{*}{ Győr } & \multirow{2}{*}{$\begin{array}{l}\text { Vocational } \\
\text { school }\end{array}$} & $\begin{array}{l}\text { In-depth interview } \\
\text { One-to-one }\end{array}$ & & 2 & - & 06.04 .18 \\
\hline & & & $\begin{array}{l}\text { Interview } \\
\text { Peer group }\end{array}$ & & 5 & 1 & 06.04 .18 \\
\hline II. & Nyíregyháza & Highschool & $\begin{array}{l}\text { Associative task in } \\
\text { class work }\end{array}$ & $\begin{array}{l}\text { List of Values } \\
\text { Materialism }\end{array}$ & 15 & 18 & 16.05 .18 \\
\hline \multirow{5}{*}{ III. } & \multirow[b]{3}{*}{ Nagykálló } & \multirow[b]{3}{*}{$\begin{array}{l}\text { Vocational } \\
\text { school }\end{array}$} & $\begin{array}{l}\text { Interview+collage } \\
\text { One-to-one }\end{array}$ & \multirow{3}{*}{$\begin{array}{l}\text { Materialism } \\
\text { Happiness } \\
\text { Satisfaction } \\
\text { Materialism } \\
\text { Experience } \\
\text { Satisfaction } \\
\text { Status symbol } \\
\text { Money }\end{array}$} & 3 & - & 30.05 .18 \\
\hline & & & $\begin{array}{l}\text { Interview+collage } \\
\text { Peer group }\end{array}$ & & 1 & 2 & 30.05 .18 \\
\hline & & & $\begin{array}{l}\text { Associative task in } \\
\text { class work }\end{array}$ & & 41 & 8 & 30.05 .18 \\
\hline & \multirow{2}{*}{ Nyíregyháza } & \multirow{2}{*}{ Highschool } & $\begin{array}{l}\text { Interview+collage } \\
\text { One-to-one }\end{array}$ & \multirow{2}{*}{$\begin{array}{l}\text { Materialism } \\
\text { Happiness } \\
\text { Satisfaction }\end{array}$} & 3 & - & 31.05 .18 \\
\hline & & & $\begin{array}{l}\text { Interview+collage } \\
\text { Peer group }\end{array}$ & & 1 & 2 & 31.05 .18 \\
\hline & & & & Total & 78 & 34 & - \\
\hline
\end{tabular}

Since secondary school students were targeted, the construction of the sample was difficult due to two reasons. One is the strict rigorous school year and scholarship in Hungary the other reason was the schools' willingness to pariticipate in the research. Thus the sample analysed is a convenience sample involving those schools those gave the permission to ask students. The three stages were performed in January, April and May in different schools. Between these dates the research design was re-evaluated and developed, this made the design dynamic but less repeatable. The reason of geographical diversity of the sample is Budapest as the capital city is the statistically richest and most developed area of Hungary provides excellent examples on metropolitan influences. In order to balance inequality between regions we selected Györ, as the second most developed city of the country and the Eastern part of Hungary (Nyíregyháza and Nagykálló) which is one of the least developed regions. The terms highschool and vocational school mean two different secondary schools. In Hungarian education system highschool is the institute providing general knowledge, preparing for an excellent maturity exam and the doorstep of science universities. The vocational school also enables students to perform 
maturity exam but there are subjects around a given profession and students usually starts to work after secondary school years, only a few of them apply for higher education. The dates of interviews and tasks and the number of respondents are summarized in table 1.

Table 1 Interviews and associative task summary

\section{Research findings}

First stage

Respondents were asked to rate 24 values according to the importance and the realization in everyday life. ${ }^{1}$ (HofmeisterTóth, 2009) Among the six most important values (family, health, honesty, sincerety, satisfaction, progression) only honesty and satisfaction were among the top realized values. Health and progression showed big discrepancy regarding their importance and realization. Although success was not one of the most important values but it was the least realized one. We assume it is in strong relationship with progression. Respondents explained they would like to be successful but in their current state they still could not relaized the way to success. They feel they should do a lot and be improved for success. They perform well in their relationships with other it is not surprising that honesty and family are top ranked values. In general the 14 students of the first stage feel themselves happy saying interpersonal relationships contribute more to theirs sense of happiness than material goods. Money does not lead them directly to happiness but it is necessary to satisfy basic needs. One of their answer on the quations "Does money make people happy?" represents well their opinion: „No, because money can make happiness only visible. Unfortunatelly many believe they are happy because they have got everything but in fact their relationships with family, friends are not the best and this whole is just an illusion." (Female, age 17, Györ) Material possessions and tangible goods are not important for them. However they consider certain goods, the ability to spend and the freedom of consumer choices as meaningful features and they say the world today is rather materialist. During each interview smart phones and phone brands had a central role in interpretations, these can be considered as status symbols of this cohort. Although the brand and quality of phone possessed were not important for respondents but the role of personal properties is significant: „I felt myself happy when I could buy my phone from my own money collected first time in my life. I worked for it, I deserved for it, so I take proper care of this. When I just received one that was not so worthy, moreover it belongs officially to me, the possessor is me." (Male, age 18, Budapest)

\section{Second stage}

In the next phase of the research we aimed to define the values by teenagers. One highschool was selected as a field where List of Values (Kahle, et al. 1983) was conducted². 33 students worked in 3-4 person peer groups. In each group participants had to find associations to the values given as detailed above. Participants considered being well respected as success and progression in the field of studies and work, while the security meant the protection of possession and family. Materialism was rather associated with frugality. Regarding the rest of the value set fun and enjoyment was identified as experiences with friends, self-fulfilment was connected to life goals. Among the most relevant - last step of associative exercise - meaning of being well respected was the success in work, safety was the family and materialism was equal to frugality.

\section{Third stage}

As the last phase of the research peer group associations and in-depth interviews combined with photo collage method were taken in a highschool and a vocational school. In accordance with previous findings respondents confirmed the less important role of material goods for the sense of happiness.

\section{Peer group associations}

According to the research design participants collected all the relevant associations with money, success, happiness, status symbol, experience and materialism. As represented in table 2 respondents wrote the most associations with happiness and the least with materialism. The associations were the most concentrated in case of happiness because $55 \%$

\footnotetext{
${ }^{1}$ Health, family, security, happiness, honesty, vitality, sincerety, harmony, freedom, satisfaction, autonomy, wealth, charity, order, intelligence, performance, progression, success, frugality, fun and enjoyment, originality, education, being respected, modesty ${ }^{2}$ Being well respected, excitement, fun and enjoyment, security, self-fulfilment, self-respect, sense of accomplishment, sense of belonging, warm relationships with others
} 
of the findings were the same or with similar meaning. Despite of the small number of associations materialism and status symbol were the least concentrated so the notion of students was far-reaching. These results confirm the expectation that teenagers do not consciously use status symbol or this definition is not obviously clear. On the other hand materialism is rather about the people's relationship with money. The success, experience, money and happiness terms were interpreted similarly or with the same meaning.

\begin{tabular}{|c|c|c|c|c|c|c|}
\hline & Money & Success & Happiness & Status symbol & Experience & Materialism \\
\hline $\begin{array}{r}\text { Total number of } \\
\text { associations }\end{array}$ & 87 & 86 & 91 & 68 & 76 & 53 \\
\hline $\begin{array}{r}\text { Number of } \\
\text { associations without } \\
\text { similarities }\end{array}$ & 45 & 50 & 41 & 41 & 39 & 39 \\
\hline $\begin{array}{r}\text { Proportion of similar } \\
\text { associations }\end{array}$ & $48 \%$ & $41 \%$ & $55 \%$ & $39 \%$ & $49 \%$ & $26 \%$ \\
\hline $\begin{array}{r}\text { Associations } \\
\text { occurred more than } \\
\text { twice }\end{array}$ & 9 & 11 & 9 & 5 & 6 & 3 \\
\hline $\begin{array}{r}\text { Proportion of } \\
\text { associations } \\
\text { occurred more than } \\
\text { twice }\end{array}$ & $60 \%$ & $65 \%$ & $60 \%$ & $36 \%$ & $67 \%$ & $33 \%$ \\
\hline
\end{tabular}

Table 2 Summary of third stage associations

Money associations can be grouped in three categories: acquisition (e.g. work, salary), spending (e.g. shopping, some kinds of goods) and state of existence (e.g. richness, being successful). Since respondents mentioned work 13 times work was the most frequent among all findings - we can assume that work, job, further carrier dominate the students' notions about money. Among the associations occurred minimum twice the most were related to spending mainly everyday material possessions such as car, food, appeal, house.

Success findings also can be formed into three groups: external confirmation (e.g. acknowledgment, reward), inspirations and achievement (e.g. victory, studies, driver license) and work (workplace, carrier). Inspirations are firstly manifestations of personal achievements (e.g. maturity exam, good grades, driver license) secondly are general (happiness, studies, life goals), thirdly are related to rivalry (victory, competition). Although money is not defeinitely connects to these subgroups, it is also frequently mentioned under success. Thus we cannot exclude the interpretation of success as material succss or wealth. If we consider money-work-success relationship we can derive a conclusion about teenagers perception: the more the salary the more acknowledged the professional can be the signs of success.

Happiness items also can be grouped into three subgroups: relationship with others (e.g. family, friends), possessions (e.g. money, food) and success related items (e.g. success, life goals). The associations occurred more than twice are friends, family, love, marriage, children. Based on the sample analysed we can assume that happiness is strongly connected with interpersonal relationships.

Status symbol was hard for respondents to define through association. Nonethless two interpretations seem to be characterized. First is obviously the material possession including car, phone or jewelry? Second is personal trait category such as ability to lead, managing a business or being successful. Probably these personal traits can be important for the legitimation to possess status symbols or simply being or deserved for status symbols.

Experience associations can not be categorized as above but there is a tendency towards enjoyment that was mentioned 11 times. The second most frequent were the trip and holiday. Beside the forms of entertainment and gaining experiences there were personal associations such as friends or family. These confirm the central role of personal relationships. Instead of "what?" and "where?" questions the "with whom?" is the most relevant.

Materialism associatons can be categorized as spending and money. The spending includes general but expensive things as house or car. House and car can be considered as points of references in the age of adolescence. The reason behind can be that these two things are clearly visible evidences of someone's economic state. These are general enough - most of the people or households possess them - and the more expensive the possession the better the economic conditions. 
This realationship seems to be unambiguous for teenagers. Thirftiness and savings rule the money category. We can derive a conclusion that being materialist means rather frugality or someone who saves money rather than being attached to material goods. A relevant question is that what do they want to spend the saved money on? In this context materialist must have future goals with money, wheather is it ensuring the standard of living or the acquisition of desired material goods?

As the last step of associative task respondents had to reduce their findings an sort them according to their relevancy. So they generated a top 3 ranked category including the most relevant meanings of money, success, happiness, status symbol, experience and materialism. According to the summary represented in table 3 money is strongly associated with work that may mean the source of money. Respondents feel success if they are acknowledged and interpersonal relationships are the best for their sense of happiness. The smart phone and house are the status symbols in adolescence. Holiday gives the opportunity to gain experiences but only with people, mainly frineds. Last but not least if you ask teenagers "what is materialism?" the answer will probably be money.

\begin{tabular}{|c|c|c|c|c|}
\hline & $\begin{array}{l}\text { The most frequent } \\
\text { associations among } \\
\text { TOP } 3\end{array}$ & $\begin{array}{l}\text { The second most } \\
\text { frequent } \\
\text { associations among } \\
\text { TOP } 3\end{array}$ & $\begin{array}{l}\text { Associations occurred at } \\
\text { leat twice among TOP } 3\end{array}$ & $\begin{array}{l}\text { The most relevant } \\
\text { association (ranked by } \\
\text { respondents) }\end{array}$ \\
\hline Money & Work (10) & Food (4) & $\begin{array}{l}\text { Salary (3) } \\
\text { House (3) } \\
\text { Success (2) } \\
\text { Shopping (2) }\end{array}$ & Work (10) \\
\hline Success & Acknowledgment (3) & - & $\begin{array}{l}\text { Happiness (2) } \\
\text { Endurance (2) } \\
\text { Work (2) } \\
\text { Support (2) } \\
\text { Respect (2) }\end{array}$ & Acknowledgment (3) \\
\hline Happiness & Family (11) & Friends (5) & $\begin{array}{l}\text { Health (3) } \\
\text { Marriage (2) } \\
\text { Love (2) } \\
\text { Entertainment (2) }\end{array}$ & Family (6) \\
\hline Status symbol & $\begin{array}{l}\text { Phone (4) } \\
\text { House (4) }\end{array}$ & Car (3) & $\begin{array}{l}\text { Jewelry (2) } \\
\text { Appeal (2) }\end{array}$ & Phone (4) \\
\hline Experience & Holiday (6) & Friends (5) & $\begin{array}{l}\text { Trip/tour (4) } \\
\text { Family (3) } \\
\text { Party (2) } \\
\text { Memories (2) } \\
\text { Success (2) }\end{array}$ & $\begin{array}{l}\text { Family (2) } \\
\text { Holiday (2) }\end{array}$ \\
\hline Materialism & Frugality (4) & $\begin{array}{l}\text { Savings (3) } \\
\text { Money (3) }\end{array}$ & Car (2) & Money (3) \\
\hline
\end{tabular}

Table 3 The most relevant associations in third stage (occurence in brackets)

\section{Photo collage}

During in-depth interviews in the third stage respondents had to select from a set of photographs. The set consisted of five categories: people, material possessions, achievement, sport and leisure. Students had to choose one out of each except of leisure, they could choose maximum 3. Each category contained 4 different images except of leisure, there were 6 . In the people category there were family, friends, school mates and subculture photos. The material possessions consisted of car, smart phone, appeal and money. The achivements were excellent school grade, winning in sport, art and carrier in media. Those forms of achievement were selected as options those are probabley close to students' imagination and perception. Sport consisted of body sports, running, soccer and tennis. The research expectations were that body sports are getting more and more popular among youth, running is an options free from tangible or personal conditions (e.g. court, equipment, sport centre, teammates), soccer is a spectacular and popular sport to play or just to follow and tennis is related to higher social classes. Leisure activities set was a combination of widely different options as music, reading, own room, tracking 
in the nature, gaming console and makeup. During in-depth interviews respondents recognized these proposed features of the options. In their explanation they distinguished options in the same way. Photo collage summary including the frequency of choices are represented in table 4.

Table 4 Summary of photo collage tasks (occurence in brackets)

\begin{tabular}{|c|c|c|c|c|c|}
\hline & People & $\begin{array}{l}\text { Material } \\
\text { possessions }\end{array}$ & Achievement & Sport & Leisure \\
\hline $\begin{array}{r}\text { Respondents' } \\
\text { choices }\end{array}$ & $\begin{array}{l}\text { family (3) } \\
\text { friends (3) }\end{array}$ & $\begin{array}{l}\text { car (2) } \\
\text { appeal (3) } \\
\text { money }\end{array}$ & $\begin{array}{l}\text { excellent school } \\
\text { grades (4) } \\
\text { winning in sport } \\
\text { art }\end{array}$ & $\begin{array}{l}\text { running (5) } \\
\text { body sport }\end{array}$ & $\begin{array}{l}\text { music }(5) \\
\text { tracking in the nature }(4) \\
\text { reading }(2) \\
\text { makeup (2) } \\
\text { room (2) } \\
\text { gaming console }\end{array}$ \\
\hline
\end{tabular}

Source: own edition

People catergory was dominated by the family and friends. Students' interpretations confirmed previous research findings on the importance of the quality of personal relationships. Regarding material possessions the value in-use of the objects is more dominant than simply possessing something, in context of materials respondents follow a rather utilitarian pattern. According to students' opinion a basic level of wealth is necessary to feel themselves happy. They highlighted the importance of the security of housholds, doing the payments in time, making enough money for living and the freedom to spend. This last feature is one of the foundations of postmodern culture of consumption. "Money is not important for me at all cost, but in order to live in a safety environment, start a family, have roof over our head or just simply not to starve money is necessary. If we cannot ensure these (above mentioned) we will not be able to afford the rest, smart phone, car, appeal, etc." (Female, age 17, Nyíregyháza)

Excellent school grades are the most relevant signs of achievement for teenagers. It contributes a lot to their sense of happiness. Perhaps the importance of feedbacks comes from the usual life situation of teenagers. In general they are subordinated under parents' and teachers' power. They consider their carrier opportunities are strongly related to their school performance on the other hand school grading is not only an external acknowledgment but in this age it became their inner subjective scale. Respondents' explenations confirmed these propositons because students often explained something through the example of their studies or school grades. This phenomenon highlights the importance of an appropriate, fair grading scheme that provides the sense of equality of people evaluated. "I chose this because it makes me happy if I get a good mark. This is very important for me. Moreover it is not just a random achievement, we can do for it or perform better and it is partially up to us. Being acknowledged through your grades is one of the biggest source of happiness." (Female, age 17, Nyíregyháza)

Almost every respondents chose running as a kind of sports contributing the most to their sense of happiness. It was interesting that no one chose soccer or tennis which can be not only played but watched. This enables us to derive the conclusion respondents prefer to do sports rather than to watch it. In their interpretation students confirmed the expectation running is the way to do sport with no material possession or condition. They can run whenever and wherever they want, there is no need for a court, equipment or mates. Morevore they answered running provides the sense of freedom, escaping from everyday boundaries and the opportunity to meditation. "I chose running because this is the easiest way to do some sports. I love playing handball for instance but it must be carefully prepared, I need for a team, a court, there are a lot of constraints. Whenever I feel the motivation I can run. Maybe this is the reason why I started it regularly." (Female, age 17, Nagykálló)

From the leisure category music and tracking in the nature items were the most frequent choices. Obviously music plays a central role in motivating or relaxing someone's mind, and was very important for respondents. In their interpretation they would listen to music anytime and anywhere they are. According to students' explanation tracking in nature is close to running in the context of freedom and the lack of usual boundaries, but it is also close to experiences - previous tasks because the mates are more important than the destination, the place where they would track. Family and friends are preferable, so we can assume leisure activities are also dominated by personal relationships. "It is important to spend leisure time in the nature with family and friends. Many do not know how the nature can gain our energy and vitality." (Female, age 17, Nyíregyháza) 


\section{Conclusions}

Answering the research title whether tangible or intangible ways are leading to happiness we can state that intangible factors are better for the sense of happiness. Although quantitative statistically reliable test was not included but the last 8 year scientific results are confirmed. Without warm relationships with others we cannot talk about the true sense of happiness. Need satisfaction by material goods at a basic level is essential but it is not the only source of happiness it just enables individuals to focus on intangible factors. According to respondents the material possessions or money do not gain directly happiness. Possessions and money are necessary to everyday life but not for being happy. Recent paper provides a proposition on subject-object relationship: during the time of adolescence they do not feel the need for more objects, goods to possess. One reason behind may be material saturation. There are so many objects, goods available around them that their acquisitiveness and possessiveness are getting less and less. Regarding satisfaction in this age external feedbacks and acknowledgements are essential. Respondents have a huge demand for a reliable and transparent evaluation system on their work. This demand can be caused by their uncertainty and the wanting to know weather they are on the right way or not. Since the success in their future profession and the school performance are considered as strongly related to each other in the now they want to perform as well as they can. Work plays a more central role in their life than expected. They associated a lot of phenomena with work. It can be caused by their perceptions about adults' life and challenges or by the turnaround in postmodernity. We can assume that work or professional motivations are not simply the instruments or ways anymore to achieve a desired consumer state of existence. Based on respondents' interpretations work has a symbolic meaning, it is a calling again. If they find the best job for their personality it will make them satisfied with their life. Beside its importance work means the only source of money and being materialist is understood as the individuals' relationship with money: spending or saving. Frugality is a remarkably common association of materialism. In their explanation respondents are trying to save as much money as they can. This behaviour can be influenced by life experiences and the avoidance of personal financial crisis or by consumer motivations for the future.

Limitations further research

Recent study did not follow strict pretested methodology. Due to the applied methods' flexibility and interactivity it is difficult to repeat or replicate. Nonetheless it provided several conclusions helping other studies on similar or the same research field. First revealing the general meaning of the investigated social-economic features among the members of target group can result fruitful information. Second in different life stages - especially ages like adolescence, young adulthood individuals can be defended by their current state of existence. For instance an average teenager does not have to run a household, earn her or his own money for living, thus she or he has diverse perception of money. During secondary school years teenagers are surrounded by usually the same people. Their everyday routine and interactions are following the same pattern and they may not feel their real position in the world or social order. The beginning university studies opens up the world: new contacts, interaction with members of unknown socio-economic state. This can cause the re-evaluation of previous value concept including the attachment of material possessions. If a young adult or an older teenager starts to work as a full-time employee this will be another new situation much different from ordinary school years. Tangible assets gain new meaning, money and salary becomes the measure of value and youngsters are getting forced to start their own uniqe life. In these changes of the near future for a teenager the motives of consumption, tangible things possessed or desired and a lot of costly constraints are playing essential role. Therefore longitudinal generational studies and lifestyle trackings could take us closer to understand the role of material things in consumer society.

\section{References}

[1] Audrin, C. - Brosch, T. - Chanal, J, - Sander, D. (2017): When symbolism overtakes quality: Materialists consumers disregard product quality when faced luxury brands. Journal of Economic Psychology. 61. 115-123.

[2] Bauman, Z. (1991): A sociological theory of postmodernity. Thesis Eleven. 29 (1) 33-46.

[3] Belk, R. W. (1983): Wordly Possessions: Issues and Criticisms. Advances in Consumer Research. 10. 514-519.

[4] Belk, R. W. (1984): Three scales to measure constructs related to materialism: reliability, validity and relationships to measure of happiness. Advances in Consumer Research. 11. 291-297.

[5] Campbell, C. (2005): The romantic ethic and the spirit of modern consumerism. Alcuin Academics. Oxford. 
[6] Carter, T. J. - Gilovich, T. (2012): I am what I do, not what I have: the centrality of experiential purchases to the self-concept. Journal of Personality and Social Psychology. 102. 1304-1317.

[7] Chaplin L. N, John R. D. (2010): Interpersonal influences on adolescent materialism: A new look at the role of parents and peers. Journal of Consumer Psychology, 20: 176184.

[8] Csikszentmihaiyi, M, Rochberg-Halton, E. (1978), "Reflections on Materialism," University of Chicago Magazine, 70 (3), 6-15.

[9] Csíkszentmihályi, M. (2002): Flow: The psychology of happiness: The classic work on how to achieve happiness. Rider. London.

[10] Debreceni, J. - Hofmeister-Tóth, Á. (2018): Materialism among teenagers, the relationship between terminal values and social media use. International Journal of Multidisciplinarity in Business and Science. 4 (5) 5-12.

[11] Debreceni, J. (2018): Merre tart az anyagiasság-kutatás?: Az elmúlt nyolc év meghatározó kutatási eredményeinek összefoglalása. In: Józsa, L. et al (2018): A hatékony marketing. EMOK 2018 Nemzetközi Tudományos Konferencia konferenciakötete. Komárno, Szlovákia, 2018.08.27-2018.08.28. Selye János Egyetem, pp. 148-159.

[12] Deckop, J. R. - Jurkiewicz, C. L. - Giacalone, R. A. (2010): Effects of materialism on work-related personal wellbeing. Human Relations. 63 (7) 1007-1030.

[13] Flynn, L. - Goldsmith, R. E. - Pollite, W. (2016): Materialism, status consumption and market involved consumers. Psychological Marketing. 33 (9) 761-776.

[14] Fournier, S. - Richins, M. L. (1991): Some Theoretical and Popular Notions concerning Materialism. Journal of Social Behavior and Personality. 6. 403-414.

[15] Gardasdóttir, R. B. - Dittmar, H. (2012): The relationship of materialism to dept and financial well-being: The case of Iceland's perceived prosperity. Journal of Economic Psychology. 33. 471-481.

[16] Gibbins, K. - Walker, I. (1993): Multiple interpretations of the Rokeach Value Survey. The Journal of Social Psychology. 133 (6) 797-805.

[17] Goldsmith, R. E. - Clark, R. A. (2012): Materialism, Status Consumption, and Consumer Independence. The Journal of Social Psychology. 152 (1) 43-60.

[18] Harnish, R. J. - Bridges, K. R. (2014): Compulsive buying: The role of irrational beliefs, materialism and narcissism. Journal of Rational-Emotive and Cognitive Behavior Therapy. 33. 1-16.

[19] Hofmeister, Á. - Neulinger, Á. (2013): Characteristics of materialism and its measurement: assessing the Belk's materialism scale in Hungary. International Journal of Consumer Studies. 37. 320-326.

[20] Hofmeister-Tóth Á. - Eibel-Spányi K. (2013): The impact of values on consumer behavior. International Journal of Economics and Business. 5 (4) 400-419.

[21] Hofmeister-Tóth, Á. (2014): A fogyasztói magatartás alapjai. Akadémiai Kiadó. Budapest.

[22] Hofstede, G. - Hofstede G. J. (2010): Cultures and organizations : Software of the mind : Intercultural cooperation and its importance for survival. McGraw-Hill. New York.

[23] Hudders, L. - Pandelaere, M. (2011): The Silver Lining of Materialism: The Impact of Luxury Consumption on Subjective Well-Being. Journal of Happiness Studies. 13 (3) 411-437.

[24] Inglehart, R (1977): The silent revolution Changing Values and Political Styles Among Western Publics. Princeton University Press.

[25] Jiang, J. - Song, Y. - Ke, Y. - Wang, R. - Liu, H. (2016): Is disciplinary culture a moderator between materialism and subjective well-being? A three wave longitudinal study. Journal of Happiness Studies. 17 (4) 1391-1408. 
[26] John, R. D. (1999): Consumer socialization of children: A retrospective look at twenty-five years of research. Journal of Consumer Research. 26. 183-213.

[27] Kahle L. R. - Beatty S. E. - Homer P. (1986): Alternative Measurement Approaches to Consumer Values: The List of Values (LOV) and Values and Lifestyles (VALS). Journal of Consumer Research, 13 (December): 405409.

[28] Kasser, T. (2002): The High Price of Materialism. Mit Press.

[29] Martos, T. - Kopp, M. S. (2012): Life goals and well-being: Does financial status matter? Evidence from representative Hungarian sample. Social Indicators Research. 105. 561-568.

[30] Moschis, G. P. - Mathur, A. - Fatt, C. K. - Pizzutti, C. (2013): Effect of family structure on materialism and compulsive consumption: A Life-Course Study in Brazil. Journal of Research for Consumers. 23. 66-96.

[31] Mukerji, C. (1983), From Graven Images: Patterns of Modern Materialism, New York: Columbia University Press.

[32] Pál, E. (2013): A Z generációról. Irodalmi áttekintés. TÁMOP. Pécsi Tudományegyetem.

[33] Pikó, B. (2005): Középiskolás fiatalok szabadidő-struktúrája, értékattitüdjei és egészségmagatartása. Szociológiai Szemle. 2. 88-99.

[34] Rassuli, K.M., Hollander, S.C. (1986), "Desire-Induced, Innate, Insatiable?" Journal of Macromarketing, 6 (Fall), 4-24.

[35] Richins, M. L. - Dawson, S. (1992): A consumer values orientation for materialism and its measurement: scale development and validation. Journal of Consumer Research. 19 (December) 303-316

[36] Rokeach, M. (1973): The nature of human values. New York. Free Press.

[37] Schwartz, S. H. (2006). A theory of cultural value orientations: Explication and applications. Comparative Sociology, 5, 136-182.

[38] Szondy, M. (2007): Anyagi helyzet és boldogság: kapcsolat individuális és nemzetközi szinten. Mentálhigiéné és Pszichodinamika. 8 (4) 291-307.

[39] Tóth, I. Gy. (2016): Középosztály(ok) Magyarországon és Európában. In: Kolosi, T. - Tóth, I. Gy. (2016): Társadalmi Riport 2016. TÁRKI. Budapest. 75-97.

[40] Varga, K. (2003): Értékek fénykörében. Akadémiai Kiadó. Budapest.

[41] Villadefrancos, E. - Otero-Lopez, J. M. (2016): Compulsive buying in university students: Its prevalence and relationship with materialism, psychological distress symptons, and subjective well-being. Comprehensive Psychiatry. 65. 128-135.

[42] Weaver, S. T. - Moschis, G. P. - Davis, T. (2011): Antecedents of materialism and compulsive buying: A life course study in Australia. Australian Marketing Journal. 19. 247-256.

[43] Weber, M. (1915): The social psychology of world religions. Essay. In: Füstös, L, Tárnok, O. (2013): Értékváltozás Magyarországon 1978-2009. Értékváltozás vagy értékválság? Pázmány Péter Katolikus Egyetem Bölcsészet- és Társadalomtudományi Kar

[44] Zhang, J. - Howell, R. - Caprariello, P. A. - Guevarra, D. A. (2014): Damned if they do, damned if they don't: material buyers are not happier from material or experiential consumption. Journal of Responsible Personal. 50. 71-83. 